\title{
Ex-situ bioremediation of polycyclic aromatic hydrocarbons in sewage sludge
}

\author{
J. E. Schmidt ${ }^{1,2}$, S. B. Larsen ${ }^{2,3}$ \& D. Karakashev ${ }^{2}$ \\ ${ }^{I} N R G$, Biosystems Department, Risø DTU - National Laboratory for \\ Sustainable Energy, Technical University of Denmark, 4000 Roskilde, \\ Denmark \\ ${ }^{2}$ Department of Environmental Engineering, \\ Technical University of Denmark, 2800 Lyngby, Denmark \\ ${ }^{3}$ Present address: EnviDan, Fuglebcekvej 1B, 2770 Kastrup, Denmark
}

\begin{abstract}
Polycyclic aromatic hydrocarbons (PAH) are naturally occurring organic compounds. As a result of anthropogenic activities, PAH concentration has increased in the environment considerably. PAH are regarded as environmental pollutants because they have toxic, mutagenic and carcinogenic effects on living organisms. A promising approach to reduce PAH pollution is based on the implementation of the natural potential of microorganisms to utilize hydrocarbons. In this study Proteiniphilum acetatigenes was used for bioaugmentation during anaerobic digestion of sewage sludge to improve the PAH removal. Primary and mixed (primary: secondary sludge $=1: 3$ ) sewage sludges were collected from a waste water treatment plant (WWTP) and degraded under mesophilic anaerobic conditions. The primary and mixed sludge produced separately from this digestion was used for three bioaugmentation batch experiments: firstly, with the addition of bacteria in the beginning of the experiment; secondly, with the addition of bacteria in the beginning and then every second and third day, with the addition of encapsulated bacteria in the beginning. Batch performance was monitored by following volatile fatty acids and methane production during degradation of $\mathrm{PAH}$ found in the sludge. Results obtained showed that the performances of the first two batch experiments were positively affected by the introduced strains. However, no preference towards individual PAH degradation was observed, but the methane production in the batches with the encapsulated cells was strongly inhibited due to tannin production during alginate lysis. A clear preference for naphthalene removal was also registered due to PAH diffusion problems through the alginate beads. It was shown that the primary sludge had better potential for PAH removal compared to mixed sludge. This was due to lower organic content in the primary sludge facilitating PAH bioavailability for the introduced microorganisms.
\end{abstract}

Keywords: bioremediation, PAH, sewage sludge. 


\section{Introduction}

Polycyclic aromatic hydrocarbons $(\mathrm{PAH})$ are naturally occurring organic compounds, consisting of three or more fused aromatic rings. PAH are regarded as environmental pollutants by environmental and health agencies because they have toxic, mutagenic and carcinogenic effects on the living organisms (Samanta et al [16]). As a result of anthropogenic activities the concentration of PAH in the environment increased considerably.

$\mathrm{PAH}$ are formed during the combustion of different organic materials e.g. coal, cigarettes, fossil fuels and in relation to domestic heating (Polycyclic aromatic hydrocarbons (PAHs) [14]). Therefore the most common source of $\mathrm{PAH}$ in the environment is air pollution. Through the air, the PAH can deposit to water bodies and soil (Welker [20]). PAH also deposits on surfaces of roads by, which they enter the sewage system through runoff after rainy events (Wada et al [19]). Through the common sewer system they end up at the wastewater treatment plants (WWTP). Due to the hydrophobicity of PAH, they absorb to the particulate matter in wastewater sludge, hence they end up in the sewage sludge. Sewage sludge have been disposed through several ways, among these are agricultural land application, ocean dumping and incineration, where land application is the most frequently used. However, disposal of sewage sludge on land posses a potential risk to the environment especially with respect to $\mathrm{PAH}$ content.

A promising approach to reduce $\mathrm{PAH}$ pollution is the implementation of the natural potential of microorganisms to utilize hydrocarbons since the bioremediation techniques are cheaper than the other alternatives (soil washing, solidification and stabilization, incineration, thermal treatment or advanced oxidation processes) used for cleaning up of contaminated sites (Clarinet. Remediation of Contaminated Land. Technology Implementation in Europe [6]).

The overall goal of the present study was to remediate (in terms of PAH) sewage sludge by means of bioaugmentation at anaerobic conditions. Bioaugmentation have been previously used as a tool for bioremediation of wastewaters, especially in relation to activated sludge [Boon et al [5]; Dionisi et al [7]). Anaerobic bioremediation of PAH contaminated anaerobic environments such as aquifers and marine sediments has been widely studied (Bamforth and Singleton [3]). Anaerobic PAH biodegradation in synthetic medium was also previously studied with a mixed microbial consortium (Zhang et al [21]) and with a pure culture (Fuchedzieva et al [9]) isolated from a wastewater treatment plant. However, anaerobic PAH biodegradation in sewage sludges with addition of exogenous (bioaugmented) anaerobic microorganisms known to degrade $\mathrm{PAH}$, has not been investigated till now. The approach of bioaugmentation is very important, as it was often observed that the introduced microorganisms die shortly after the addition due to abiotic (nutrients availability, toxic levels of pollutants etc.) and biotic stress (competitive and antagonistic interactions with respect to indigenous microflora) (Blanchard et al [4], Ressler et al [15]).

In our study three different bioaugmentation approaches were tested with respect to obtain maximum removal of $\mathrm{PAH}$ in primary and mixed sewage 
sludge. An isolate of Proteiniphilum acetatigenes, able to degrade $\mathrm{PAH}$ in synthetic media under anaerobic methanogenic conditions, was used for bioaugmentation.

\section{Materials and methods}

\subsection{Sludge collection and characterization}

Primary, mixed (primary: secondary sludge $=1: 3$ ) and anaerobically digested sewage sludge were collected from a wastewater treatment plant (Lundtofte, Denmark) and analysed for total chemical oxygen demand (COD), volatile solids (VS) and PAH (naphthalene, acenaphtene, anthracene, fluoranthene, phenatrene, pyrene, benzo(k)fluoranthene, benzo(a)pyrene) content (Table 1). In order to have homogenous substrate for the bioaugmentation, the primary and mixed sludge were degraded with anaerobically digested sewage sludge as inoculum $(50 \%)$ under mesophilic $\left(37^{\circ} \mathrm{C}\right)$ anaerobic batch conditions and hydraulic retention time of 20 days in continuously stirred tank reactors (CSTR) with working volume $2 \mathrm{~L}$. These digested sludges were used for the bioaugmentations experiments.

Table 1: $\quad$ Characteristics of the different sludges collected.

\begin{tabular}{llll}
\hline Parameter & Unit & $\begin{array}{l}\text { Primary sludge } \\
\left(\mathrm{mean} \pm \mathrm{SD}^{\mathrm{a}}\right)\end{array}$ & $\begin{array}{l}\text { Mixed sludge } \\
(\mathrm{mean} \pm \mathrm{SD})\end{array}$ \\
\hline Total COD & $\mathrm{g} \cdot \mathrm{L}^{-1}$ & $18.2 \pm 0.90$ & $43.8 \pm 2.30$ \\
VS & $\mathrm{g} \cdot \mathrm{L}^{-1}$ & $16.2 \pm 0.71$ & $38.1 \pm 1.40$ \\
Naphthalene & $\mu \mathrm{g} . \mathrm{L}^{-1}$ & $6.3 \pm 0.22$ & $6.9 \pm 0.24$ \\
Acenaphtene & $\mu \mathrm{g} . \mathrm{L}^{-1}$ & $4.6 \pm 0.15$ & $3 \pm 0.11$ \\
Anthracene & $\mu \mathrm{g} . \mathrm{L}^{-1}$ & $9.6 \pm 0.39$ & $7.1 \pm 0.25$ \\
Phenatrene & $\mu \mathrm{g} . \mathrm{L}^{-1}$ & $1 \pm 0.04$ & $1.2 \pm 0.04$ \\
Fluoranthene & $\mu \mathrm{g} \cdot \mathrm{L}^{-1}$ & $12.5 \pm 0.42$ & $13.7 \pm 0.05$ \\
Pyrene & $\mu \mathrm{g} . \mathrm{L}^{-1}$ & $9 \pm 0.37$ & $11.6 \pm 0.42$ \\
Benzo(k)Fluoranthene & $\mu \mathrm{g} \cdot \mathrm{L}^{-1}$ & $2.5 \pm 0.10$ & $2.8 \pm 0.12$ \\
Benzo(a)Pyrene & $\mu \mathrm{g} . \mathrm{L}^{-1}$ & $1 \pm 0.04$ & $1.2 \pm 0.05$ \\
\hline
\end{tabular}

${ }^{\mathrm{a}}$ Standard deviations (SD) were based on triplicate analysis.

\subsection{Bioaugmentation batch experiments}

$120 \mathrm{ml}$ anaerobically digested sludge (primary or mixture of primary and secondary sewage sludge) were dispensed in $300 \mathrm{ml}$ glass bottles and closed with Teflon coated rubber stoppers and aluminium caps. Bottles headspace was flushed with nitrogen to ensure anaerobic conditions. The retention time was 20 days. Every second day $12 \mathrm{ml}$ of sludge was removed and a new digested sludge was added to the bottles.

Three different bioaugmentation approaches were studied: first, with addition of bacteria in the beginning of the experiment; second, with addition of bacteria in the beginning and every second and third day, with addition of encapsulated bacteria in the beginning (Figure 1). $12 \mathrm{ml}$ bacterial culture $\left(\mathrm{OD}_{600}=0.9\right)$ of Proteiniphilum acetatigenes (OD) was used for bioaugmentation at the corresponding day (Approach 1 and Approach 2). $62 \mathrm{~g}$ of alginate beads carrying 


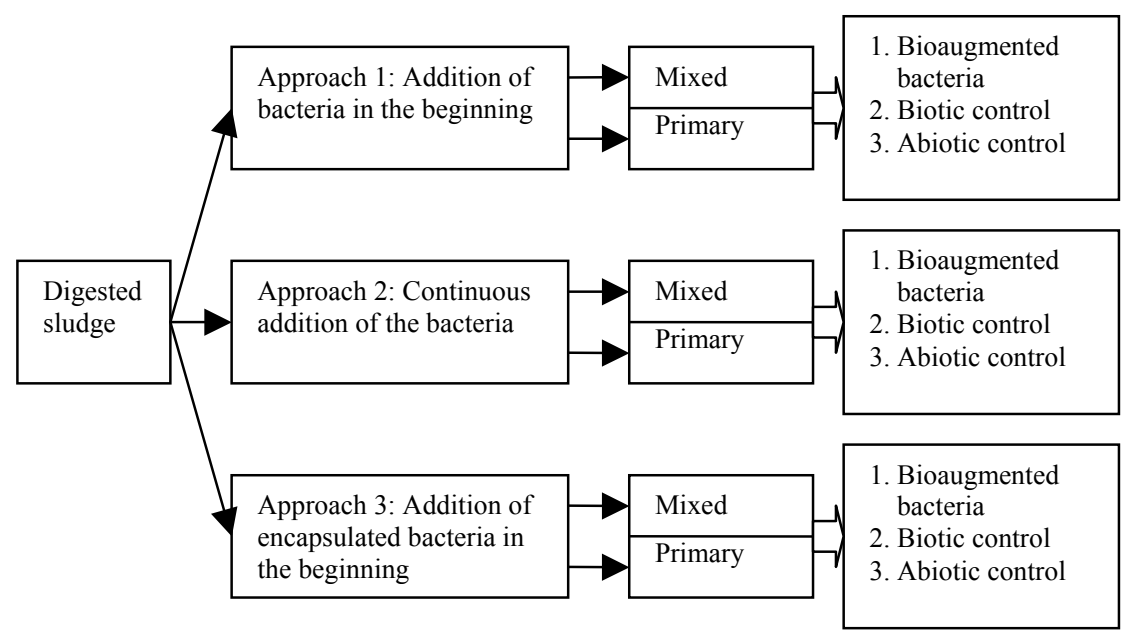

Figure 1: Overview of the bioaugmentation approaches studied.

$12 \mathrm{ml}$ bacterial culture of Proteiniphilum acetatigenes $\left(\mathrm{OD}_{600}=0.9\right)$ was used for bioaugmentation in Approach 3.

An abiotic control to evaluate the amount of PAH removed by abiotic processes (adsorption, volatilisation) and a biotic control to evaluate the amount of PAH degraded without bioaugmented bacteria was set up for all experiments. The abiotic control was prepared by autoclaving $120 \mathrm{ml}$ sludge for $30 \mathrm{~min}$ at $140^{\circ} \mathrm{C}$ in order to ensure no biological activity. The biotic control consisted of $120 \mathrm{ml}$ sludge, which was not bioaugmented.

All bioaugmented batches and controls were incubated in the dark at $37^{\circ} \mathrm{C}$ until no changes in the PAH removal rate, volatile fatty acids and methane production were registered. Every second day liquid and gas samples were withdrawn for evaluation of batch performance. Liquid samples were containing sludge were used for determination of PAH and volatile fatty acids content respectively. Gas samples from the headspace were used for analysis of methane content.

\subsection{Bacterial culture used for bioaugmentation}

A microbial culture of Proteiniphilum acetatigenes, utilizing PAH at strict anaerobic methanogenic conditions, was previously isolated (manuscript in preparation) from activated sludge received from a municipal wastewater treatment plant (Lundtofte, Denmark). The stock culture was maintained at $4^{\circ} \mathrm{C}$ on agar slants containing $0.5 \%$ nutrient broth (MPB) through regular subculturing. A loopfull from an agar slant of this culture was used to prepare an inoculum in basic anaerobic (BA) medium (Angelidaki et al [2]) autoclaved at $115^{\circ} \mathrm{C}$ for $20 \mathrm{~min}$ and supplemented aseptically with naphthalene and filter $(0.45 \mu \mathrm{m})$ sterilized yeast extract to final concentration of $0.2 \mathrm{~g} . \mathrm{L}^{-1}$ and $2 \mathrm{~g} . \mathrm{L}^{-1}$ respectively. Prior to inoculation, the medium was dispensed under anaerobic conditions by flushing the headspace of the vessels with sterile gas mixture of 
$\mathrm{N}_{2}: \mathrm{CO}_{2}(80: 20, \mathrm{v} / \mathrm{v})$. After 3 days incubation at $37^{\circ} \mathrm{C}$ cell suspensions were centrifuged and washed three times in sterile BA medium in order to remove nutrients. Washed cells diluted in $\mathrm{BA}$ medium to $\mathrm{OD}_{600}=0.9$ were used as inoculum in the bioaugmentation experiments.

\subsection{Encapsulation in alginate beads}

Alginate beads for bacterial immobilisation were prepared by adding $0.8 \mathrm{~g}$ of alginic acid sodium salt (Fluka 71238) to $80 \mathrm{ml}$ of exponentially grown cells of Proteiniphilum acetatigenes. The mixture was dropped into a sterile $0.2 \mathrm{M} \mathrm{CaCl}_{2}$ solution as previously described (Krasaekoopt et al [10]). The resulted beads (diameter $2 \mathrm{~mm}$ ) were collected aseptically and used for bioaugmentation experiments.

\subsection{Analyses}

Total chemical oxygen demand (COD) and volatile solids (VS) of the sludges were measured according to standard methods (APHA [1]). Methane and volatile fatty acids (VFA) content were analysed by gas chromatography equipped with FID detector as previously described (Sorensen et al [17]). Concentration of the individual PAH (naphthalene, acenaphtene, anthracene, fluoranthene, phenatrene, pyrene, benzo(k)fluoranthene, benzo(a)pyrene was monitored by using GC-MS with flame ionization detection (Paterau et al [13]).

\section{Results and discussion}

\subsection{Initial anaerobic digestion of the sludges collected}

Initial methanogenic anaerobic digestion of the primary and mixed sewage sludge was done to produce a homogeneous substrate for the bioaugmented experiments. During this process total COD and VS was reduced with $38 \%$ and $33 \%$ for primary sludge and with $41 \%$ and $49 \%$ for mixed sludge respectively. The VFA production was stable with acetate and propionate as the main intermediates for methane production.

No significant total PAH removal (less than $10 \%$ from the initial concentration) was observed during initial anaerobic digestion of the sludges collected (data not shown). The small decrease in PAH concentration can be explained with abiotic processes, such as adsorption to rubber stoppers and internal glass surface of the bottles (Blanchard et al [4]; Trably et al [18]). The concentration variations were not due to biodegradation as the level of easiest degradable PAH with low molecular weight such as naphthalene, fluoranthene and phenatrene was quite stable over time.

\subsection{Batch performance of bioaugmentation Approach 1: addition of bacteria in the beginning}

The overall aim of this part of the study was to determine whether or not the bioaugmented bacteria after single addition, could establish sufficient growth in order to degrade anaerobically PAH in the sewage sludges, primary and mixed. 
In all bioaugmented batches, both with primary and with mixed sludge, methane production and VFA concentration were significantly higher compared to methane production in the biotic control (data not shown). This indicated biodegradation of PAH mediated by bioaugmented bacteria with methane as end degradation product formed by methanogenic archae presented in the indigenous microbial consortium (Trably et al [18]). All abiotic controls had a very low methane and VFA content indicated absence of any microbial activity. Bioaugmented batch with primary sludge showed higher removal of PAH compared to bioaugmented batch with mixed sludge (Table 2). This finding can be explain with higher organic matter content, respectively COD of the mixed sewage sludge (Table 1) resulting in more tightly binding of $\mathrm{PAH}$ into the organic matrix, thereby decrease of PAH bioavailability to exogenous bacteria. It was previously estimated that between $10-20 \%$ of PAH content will be too complexly bound in the particulate organic matter, which limit its bioavailability to an extend where it can not be biodegraded (Ressler et al [15]).

Increase of some PAH (phenatrene, pyrene) concentration in the bioaugmented batches compared to abiotic controls was also observed. It is most probably due to the sink effects, as the new sludge was added every second day to the bioaugmented batches but not to the abiotic controls.

Table 2: PAH degradation with primary and mixed sludge and bioaugmented bacteria added in the beginning.

\begin{tabular}{|c|c|c|c|c|c|}
\hline \multirow{2}{*}{\multicolumn{2}{|c|}{ PAH }} & \multicolumn{2}{|c|}{ Primary sludge } & \multicolumn{2}{|c|}{ Mixed sludge } \\
\hline & & $\begin{array}{c}\text { Concentration } \\
\text { change in the } \\
\text { bioaugmented } \\
\text { batch } \\
\text { compared to } \\
\text { biotic control }\end{array}$ & $\begin{array}{l}\text { Concentration } \\
\text { change in the } \\
\text { bioaugmented } \\
\text { batch } \\
\text { compared to } \\
\text { abiotic control }\end{array}$ & $\begin{array}{c}\text { Concentration } \\
\text { change in the } \\
\text { bioaugmented } \\
\text { batch } \\
\text { compared to } \\
\text { biotic control }\end{array}$ & $\begin{array}{c}\text { Concentration } \\
\text { change in the } \\
\text { bioaugmented } \\
\text { batch } \\
\text { compared to } \\
\text { abiotic control }\end{array}$ \\
\hline & Naphthalene & $(--)^{\mathrm{a}}$ & $(-)^{b}$ & $(--)$ & $(--)$ \\
\hline & Acenaphtene & $(--)$ & $(/)^{\mathrm{c}}$ & $(/)$ & $(-)$ \\
\hline & Anthracene & $(--)$ & $(-)$ & $(/)$ & $(/)$ \\
\hline & Phenatrene & $(--)$ & $(+)^{d}$ & $(/)$ & $(-)$ \\
\hline & Fluoranthene & $(--)$ & $(/)$ & $(/)$ & $(/)$ \\
\hline & Pyrene & $(-)$ & $(/)$ & $(/)$ & $(+)$ \\
\hline & enzo(k)Fluoranthene & $(--)$ & $(/)$ & $(/)$ & $(-)$ \\
\hline & Benzo(a)Pyrene & $(-)$ & $(/)$ & (/) & $(-)$ \\
\hline \multicolumn{6}{|c|}{$\begin{array}{l}\text { Indicates a small decrease (up to } 2 \text { times) in individual PAH concentration in the } \\
\text { bioaugmented batch compared to biotic/abiotic control. }\end{array}$} \\
\hline b (--) & \multicolumn{5}{|c|}{$\begin{array}{l}\text { Indicates a large decrease (between } 2 \text { to } 5 \text { times) in individual PAH concentration in the } \\
\text { bioaugmented batch compared to biotic/abiotic control. }\end{array}$} \\
\hline c $(/)$ & \multicolumn{5}{|c|}{$\begin{array}{l}\text { Indicates that no change in individual PAH concentration in the bioaugmented batch } \\
\text { compared to biotic/abiotic control. }\end{array}$} \\
\hline $\mathrm{d}(+)$ & \multicolumn{5}{|c|}{$\begin{array}{l}\text { Indicates an increase (up to } 2 \text { times) in individual PAH concentration in the bioaugmented } \\
\text { batch compared to biotic/abiotic control. }\end{array}$} \\
\hline
\end{tabular}

\subsection{Batch performance of bioaugmentation Approach 2: continuous addition of bacteria}

The aim of this part of the study was to study the possibility of adjust the sludges indigenous microbial consortium to the exogenous bioaugmented 
bacteria by adding them continuously. This approach will clarify if the amount of added bacteria is the limiting factor in PAH biodegradation in sewage sludge.

Trendlines for methane and VFA production were similar as in the previous bioaugmentation approach indicating anaerobic methanogenic pathway for removal of $\mathrm{PAH}$.

Table 3: PAH degradation with primary and mixed sludge and bioaugmented bacteria added continuously.

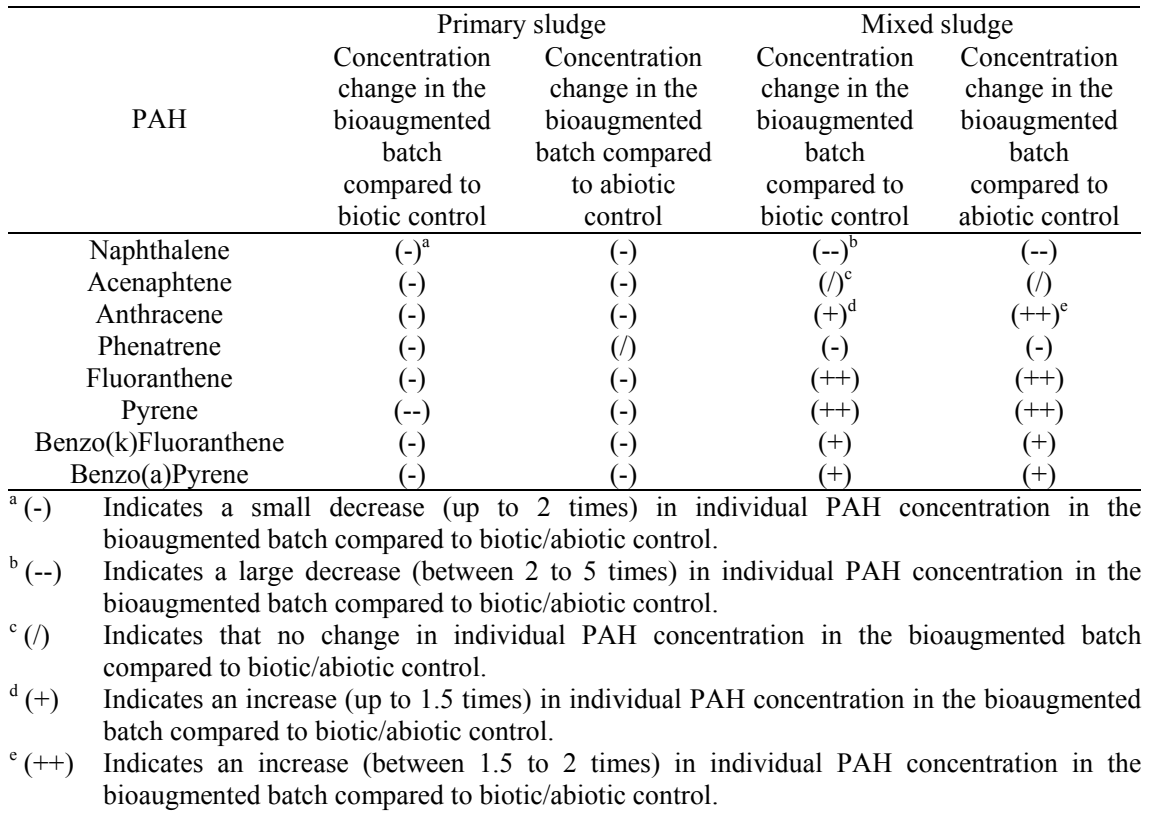

Bioaugmented primary sludge showed higher removal of PAH compared to bioaugmented mixed sludge (Table 3), which can be explained again with limited bioavailability of PAH due to high organic matter content of the mixed sludge. However, concentrations of high molecular PAH - anthracene, pyrene, benzo(k)fluoranthene and benzo(a)pyrene in the abiotic and biotic controls containing mixed sludge were much lower compared to the bioaugmented batches. This finding cannot be explained only with sink effects as explained before. A more reasonable explanation is the atmospheric deposition of PAH to bioaugmented batches with mixed sludge having higher organic matter content, respectively higher PAH adsorption ability (Evans et al [8]) than primary sludge.

This could either be through rubber stoppers and tubes, but more likely it has been taken place during continuous addition of bacteria to bioaugmented batches. During this treatment there should be plenty of time for atmospheric deposition to take place, since these reactions have fast kinetics (McNally et al [11]. 


\subsection{Batch performance of bioaugmentation Approach 3: addition of encapsulated bacteria in the beginning}

The goal of this part of the study was to investigate if encapsulation in alginate beads will have any influence on the bacterial ability to survive in sewage sludge, thereby enhance the biodegradation of $\mathrm{PAH}$ compared to other approaches.

Results obtained showed that methane production in the bioaugmented batches with the encapsulated cells was strongly inhibited due to tannins production during alginate lysis (data not shown). It has been previously shown that tannins can potent methanogenic inhibitors resulting in inhibition of anaerobic biodegradation (Moen et al [12]).

Table 4: PAH degradation with primary and mixed sludge and bioaugmented encapsulated bacteria added in the beginning.

\begin{tabular}{|c|c|c|c|c|c|}
\hline \multirow{2}{*}{\multicolumn{2}{|c|}{ PAH }} & \multicolumn{2}{|c|}{ Primary sludge } & \multicolumn{2}{|c|}{ Mixed sludge } \\
\hline & & $\begin{array}{c}\text { Concentration } \\
\text { change in the } \\
\text { bioaugmented } \\
\text { batch } \\
\text { compared to } \\
\text { biotic control }\end{array}$ & $\begin{array}{l}\text { Concentration } \\
\text { change in the } \\
\text { bioaugmented } \\
\text { batch compared } \\
\text { to abiotic } \\
\text { control }\end{array}$ & $\begin{array}{c}\text { Concentration } \\
\text { change in the } \\
\text { bioaugmented } \\
\text { batch } \\
\text { compared to } \\
\text { biotic control }\end{array}$ & $\begin{array}{c}\text { Concentration } \\
\text { change in the } \\
\text { bioaugmented } \\
\text { batch } \\
\text { compared to } \\
\text { abiotic control }\end{array}$ \\
\hline & Naphthalene & $(--)^{b}$ & $(-)^{\mathrm{a}}$ & $(++)^{\mathrm{e}}$ & $(--)$ \\
\hline & Acenaphtene & $(/)^{\mathrm{c}}$ & $(/)$ & $(+)^{\mathrm{d}}$ & $(/)$ \\
\hline & Anthracene & $(-)$ & $(-)$ & $(+)$ & $(-)$ \\
\hline & Phenatrene & $(-)$ & $(/)$ & $(/)$ & $(-)$ \\
\hline & Fluoranthene & $(-)$ & $(-)$ & $(/)$ & $(/)$ \\
\hline & Pyrene & $(-)$ & $(-)$ & $(-)$ & $(-)$ \\
\hline Benz & zo(k)Fluoranthene & $(+)$ & $(+)$ & $(/)$ & $(-)$ \\
\hline & enzo(a)Pyrene & $(/)$ & $(/)$ & $(-)$ & $(-)$ \\
\hline \multicolumn{6}{|c|}{$\begin{array}{l}\text { Indicates a small decrease (up to } 2 \text { times) in individual PAH concentration in the } \\
\text { bioaugmented batch compared to biotic/abiotic control. }\end{array}$} \\
\hline \multicolumn{6}{|c|}{$\begin{array}{l}\text { Indicates a large decrease (between } 2 \text { to } 5 \text { times) in individual PAH concentration in the } \\
\text { bioaugmented batch compared to biotic/abiotic control. }\end{array}$} \\
\hline c $(/)$ & \multicolumn{5}{|c|}{$\begin{array}{l}\text { Indicates that no change in individual PAH concentration in the bioaugmented batch } \\
\text { compared to biotic/abiotic control. }\end{array}$} \\
\hline d $(+)$ & \multicolumn{5}{|c|}{$\begin{array}{l}\text { Indicates an increase (up to } 1.5 \text { times) in individual PAH concentration in the bioaugmented } \\
\text { batch compared to biotic/abiotic control. }\end{array}$} \\
\hline e $(++)$ & \multicolumn{5}{|c|}{$\begin{array}{l}\text { Indicates an increase (between } 1.5 \text { to } 2 \text { times) in individual PAH concentration in the } \\
\text { bioaugmented batch compared to biotic/abiotic control. }\end{array}$} \\
\hline
\end{tabular}

A clear preference for naphthalene removal was also registered. This was due to PAH diffusion problems through the alginate beads. Among the studied PAH, naphthalene has the lowest molecular weight resulting in easiest diffusion through the alginate beads towards bacterial cells. Furthermore, the bioaugmented bacteria have been grown on naphthalene for inoculum preparation, hence it could be expected that they have a larger affinity for degradation of naphthalene.

Primary sludge containing bioaugmented encapsulated bacteria had higher removal of $\mathrm{PAH}$ compared to the mixed sludge (Table 4) due to different organic matter content in those sludges. Increase of some PAH in the controls can be explained with the sink effects as discussed previously. 


\section{Conclusions}

In our study three different bioaugmentation approaches employing Proteiniphilum acetatigenes were investigated with respect to anaerobic biodegradation of PAH in primary and mixed sewage sludge under mesophilic batch conditions. Results obtained showed that primary sewage sludge have the highest potential for anaerobic PAH biodegradation through bioaugmentation. This was due to the lower organic matter content of the primary sludge facilitating PAH bioavailability. Bioaugmentation with single addition of bacteria seems most promising approach allowing highest removal of all studied PAH.

\section{Acknowledgements}

The financial support of BIOWASTE project (.QLK5-CT-2002-01138) and XENOMIC project (MEIF-CT-2003-500956) is gratefully acknowledged.

\section{References}

[1] American Public Health Association. Standard methods for the examination of waste and wastewater. APHA AWWA WPCF, Washington, D.C, 1985.

[2] Angelidaki, I., Petersen, S.P. \& Ahring, B.K., Effects of lipids on thermophilic anaerobic digestion and reduction of lipid inhibition upon addition of bentonite. Applied. Microbiology and Biotechnology 33, pp 469-472, 1990.

[3] Bamforth, S.M. \& Singleton I., Bioremediation of polycyclic aromatic hydrocarbons: current knowledge and future directions. Journal of Chemical Technology and Biotechnology 80, pp 723-736, 2005.

[4] Blanchard, M., Teil, M., Ollivon, D., Legenti, L. \& Chevreuil, M., Polycyclic aromatic hydrocarbons and polychlorbiphenyls in wastewaters and sewage sludges from the Paris area (France). Environmental research 95, pp 184-197, 2003.

[5] Boon, N., Top, E.M., Siciliano, S. \& Verstraete, W., Bioaugmentation as a tool to protect the structure and function of an activated-sludge microbial community against a 3 - chloroaniline shock load. Applied and Environmental Microbiology, 69 (3), pp 1511-1520, 2003.

[6] Clarinet. Remediation of Contaminated Land. Technology Implementation in Europe. http://www.clarinet.at/library/WG7_Final_Report.pdf (accessed 17 October 2007).

[7] Dionisi, D., Bertin, L., Bornoroni, L, Capodicassa, S., Papini, M.P. \& Fava, F. Removal of organic xenobiotics in activated sludges under aerobic conditions and anaerobic digestion of the adsorbed species. Journal of Chemical Technology and Biotechnology 81, pp 1496-1505, 2006.

[8] Evans, K.M., Gill, R.A. \& Robotham, P.W.J., The PAH and organic content of sediment particle size fractions. Water, Air \& Soil Pollution, 51 (1-2), pp 13-31, 1990. 
[9] Fuchedzieva, N., Karakashev, D. \& Angelidaki, I., Anaerobic biodegradation of fluoranthene under methanogenic conditions in presence of surface - active compounds. Journal of Hazardous Materials, 2007 (in press)

[10] Krasaekoopt, W., Bhandari, B. \& Deeth, H., Evaluation of encapsulation techniques of probiotics for yoghurt. International Dairy Journal, 13, pp. 3-13, 2003.

[11] McNally, D., Mihelcic, I.J. \& Lueking, D.R., Biodegradation of mixtures of polycyclic aromatic hydrocarbons under aerobic and nitrate-reducing conditions. Chemosphere 38 (6), pp 1313-1321, 1999.

[12] Moen, E., Horn, S. \& Ostgaard, K., Alginate degradation during anaerobic digestion of Laminaria hyperborean Stipes. Journal of Applied Phycology 9, pp 157-166, 1997.

[13] Paterau, D., Laforie, M., Lichtfouse, E., Caria. G., Denaix, L. \& Schmidt, J.E., Fate of LAS, NPE, PAH and PAE after sewage sludge spreading on agricultural soils: a 30 - years field - scale recording. IWA Specialized Conference- Sustainable sludge management: state of the art, challenges and perspectives, pp 753-759, 29-31 May 2006, Moscow, Russia.

[14] Polycyclic aromatic hydrocarbons (PAHs) http://www.euro.who.int/ document/aiq/5_9pah.pdf (accessed 17 October 2007).

[15] Ressler, B., Kneifel, H. \& Winter, J., Bioavailability of polycyclic aromatic hydrocarbons and formation of humic acid-like residues during bacterial PAH degradation. Applied Microbiology and Biotechnology 53, pp 85-91, 1999.

[16] Samanta, S.K., Singh, O.V. \& Jain, R.K., Polycyclic aromatic hydrocarbons: environmental pollution and bioremediation. TRENDS in Biotechnology 20, pp 243-248, 2002

[17] Sorensen, A. H., Winther-Nielsen, M. \& Ahring, B.K., Kinetics of lactate, acetate and propionate in unadapted and lactate-adapted thermophilic, anaerobic sewage sludge: the influence of sludge adaptation for start-up of thermophilic UASB-reactors. Applied Microbiology and Biotechnology 34, pp 823-827, 1991.

[18] Trably, E., Patureau, D. \& Delgenes, J.P., Enhancement of polycyclic aromatic hydrocarbon removal during anaerobic treatment of urban sludge. Water Science and Technology 48 (4), pp 53-60, 2003.

[19] Wada, Y., Ozaki, T. \& Muraoka, M., Characteristics of benzo (a) pyrene in highway runoff pollution. $10^{\text {th }}$ International Conference on Urban Drainage, 21-26 August, Copenhagen, Denmark, 2005.

[20] Welker, A. Fate and behavior of selected organic substances in the urban drainage system. $10^{\text {th }}$ International Conference on Urban Drainage, 21-26 August, Copenhagen, Denmark, 2005

[21] Zhang, X., Sullivan, E.R. \& Young L.Y., Evidence for aromatic ring reduction in the biodegradation pathway of carboxylated naphthalene by a sulphate reducing consortium. Biodegradation 11, pp 117-124, 2000. 